\title{
Obituaries
}

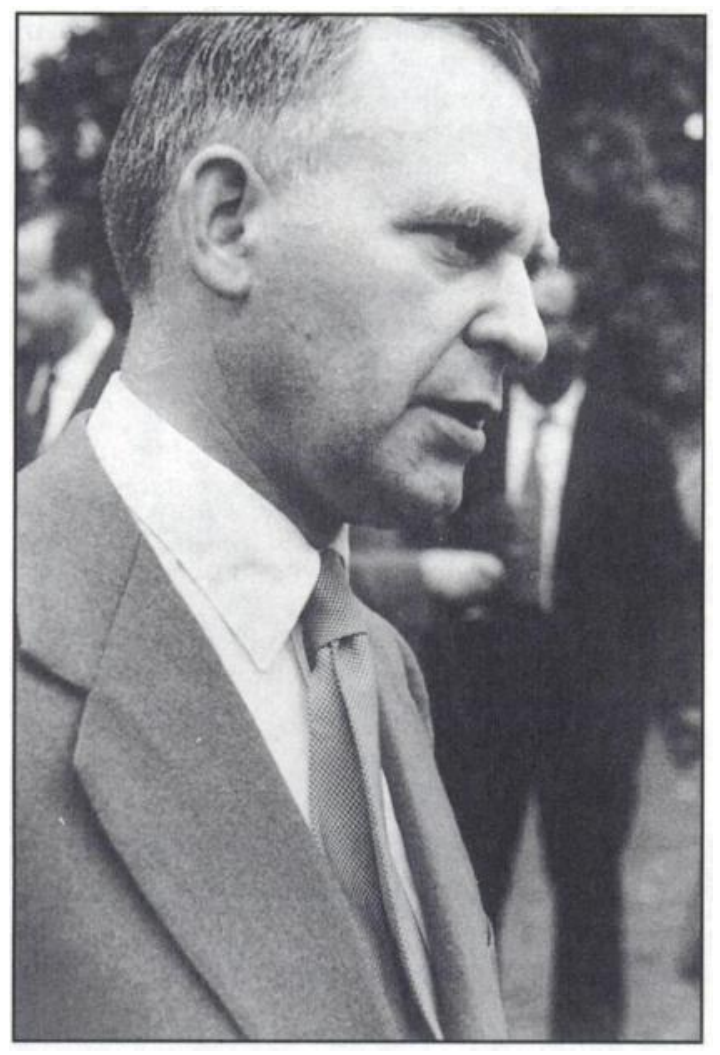

Denis Archibald Leigh, formerly Consultant Psychiatrist, Maudsley Hospital, Denmark Hill. London

Dr Denis Leigh, an Honorary Fellow of the College, died at the age of 82 on 20 April 1998. He was appointed consultant to the Bethlem Royal and Maudsley Hospitals in 1949. He was one of the very talented group of doctors who were attracted into psychiatry around the inception of the National Health Service in 1948. Extraordinary energy and talent marked his career and he made important contributions in a number of diverse fields.

Denis Leigh qualified from Manchester in 1939. gained the MRCP in 1941 and the MD in 1947. During the Second World War he served first as a regimental medical officer and then specialised in neurology. By the end of the war he was a lieutenant colonel and adviser in neurology to the eastern army in India. He maintained his military connections and served as Honorary Consultant to the British Army until 1980.

He was attracted to psychiatry by his interest in mental phenomena and by the academic opportunities of this new and expanding discipline. His training was brief by modern standards and comprised only 18 months as a registrar, mainly at the Maudsley Hospital, and a year as a clinical fellow at Harvard. He was secretly rather proud of the fact that he had no psychiatric qualification. He described himself as a "consultant physician", which was technically correct, and always wore a white coat when performing his duties at the hospital.

His first research during the War years was on the relationship between head injury and loss of smell. In 1951 he published a case report, in the Journal of Neurology, Neurosurgery and Psychiatry, on a six-month-old child entitled 'Sub-acute necrotizing encephalomyelopathy in an infant'. In the introduction he commented: ". . . the following case appears to be unique in that no references to a similar condition appear in the literature". The condition was indeed unique and has come to be known as Leigh's disease. The condition is important and has been much investigated. A recent Medline search of the literature reveals almost 300 references. It is due to an inborn error of metabolism, and in many cases a mitochondrial abnormality has been demonstrated. An autosomal inheritance is common but not invariable. To have a disease named after one is a exceedingly rare distinction.

Denis Leigh made important contributions to psychosomatic medicine. He was a founder of the European Society for Psychosomatic Research and founded, and for many years edited, the British Journal of Psychosomatic Research. His own research and publications in this area included, Bronchial Asthma. A Genetic, Population and Psychiatric Study, which was written with Ted Marley. He also translated from the French Leon Chertok's Psychosomatic Methods in Painless Childbirth.

In Who's Who he lists his recreations as "fishing and collecting". He was keenly interested in the history of medicine and psychiatry and amassed an important collection of early psychiatric books and manuscripts as well as early medical instruments. In 1961 he wrote The Historical Development of British Psychiatry. which deals with the 18th and 19th centuries. This is an interesting and scholarly work, which relies almost entirely on primary sources. It is 
enlivened by the author's pithy and commonsense judgements. In the introduction he comments: "Having been a collector since boyhood I already possessed the nucleus of a library on the subject ... the majority of the works referred to are in my (own) possession".

From 1966-78 he was Secretary General of the World Psychiatric Association. These were difficult years for an international psychiatric organisation. The scandal of Soviet attempts to use psychiatric treatments to control dissidents caused outrage. Denis Leigh fervently believed in the international nature of psychiatry and made robust, but unpopular, attempts to prevent the isolation of Russian psychiatry. During his period as Secretary General he travelled very widely and established personal contact with almost all the national psychiatric associations.

Meanwhile, at the Maudsley, he had rapidly established a busy and eclectic in-patient and out-patient unit. He had the happy knack of making complicated issues straightforward - in contrast to many psychiatrists who so often seem to make straightforward issues complicated. He brought energy, warmth and directness to the care of his patients. He was a gifted and popular teacher. Somehow he found the time to contribute to the running of the Hospital as a Governor and Chairman of the Medical Committee. He enjoyed the bucolic pastimes of gardening, fishing and shooting. At times he gave the impression that he would have been more at home as a country squire than an internationally renowned psychiatrist. However, his bluff and kindly manner concealed a sharp intellect and wide erudition.

He was much sought after as an expert in forensic and medico-legal cases. He gave evidence in a number of prominent trials. The most famous of these was that of Podola, who in 1959 , was convicted of murdering a policeman. The jury accepted Denis Leigh's evidence that Podola's excuse of amnesia was feigned and not genuine. He also gave evidence in the Lady Chatterley's Lover obscenity trial and before the European Court of Human Rights on the alleged mistreatment of IRA prisoners. He was a formidable witness: always simple and lucid in his explanations, and aided by his well-deserved reputation for fairness and integrity. He continued to maintain an extensive medico-legal practice until shortly before he was disabled by his final illness.

His wife, Pamela, three daughters and two sons survive him - one of whom, Nigel, is Professor of Neurology at King's Hospital, London.

His achievements in a number of areas were formidable, and he became one of the most well known and internationally renowned psychiatrists of his generation. Nevertheless it is by his warmth and kindness as a doctor and teacher that he will be most remembered. Like many I recall his helpfulness and generosity during the early years of my career. His comments on John Conolly serve as a fitting epitaph on his own professional life:

"Goodness and kindness were what Conolly had to give. He bequeathed to us the memory of a good and gentle man inspired by what are perhaps the most fundamental gifts the doctor can offer to his patients."

PETER Noble

\section{Personal recollection}

Denis Leigh, one of the most brilliant and important members of world psychiatry, died on 20 April 1998.

Without him the Declaration of Hawail would not have come about and we would have lost the opportunity of telling the world and ourselves that ethics must guide all we do in psychiatry. and furthermore that today this imperative is more urgently needed than ever before.

Denis Leigh served as Secretary General of the World Psychiatric Association since the world congress in Madrid 1966. It was then obvious that abuse of psychiatry was widely occurring in many places. Already, in 1969, this fact was discussed in a WPA meeting in London which was arranged by Denis at the Royal College of Physicians. The speakers at the first plenary session were: Dr R. A. Cleghorn, Canada: Professor Henry Miller, UK; Professor H. Akimoto, Japan; Arthur Koestler, UK and Professor A. V. Snezhnevsky, USSR, and it was chaired by me, not quite aware what fate held in store.

Most disturbing was that so-called dissidents in the Soviet Union were being investigated at the Serbskij Institute in Moscow and were often detained for psychiatric treatment but in the absence of mental illness. This resulted in an urgent need for the creation of ethical rules to be followed all over the world.

A proposal of an ethical committee in the WPA was put forward by me and others at the world congress in Mexico City 1971. but had to be withdrawn after the rejection by the Soviet representatives. As a compromise, and after pressure from the Americans, a small task-force was inaugurated to proceed with the work. It was Denis' idea that the group should consist of 'neutral' Scandinavians and this was approved of by Western as well as Eastern countries as the only possible solution.

I was given the responsibility of the chairmanship, and the other two were Professor Leo 